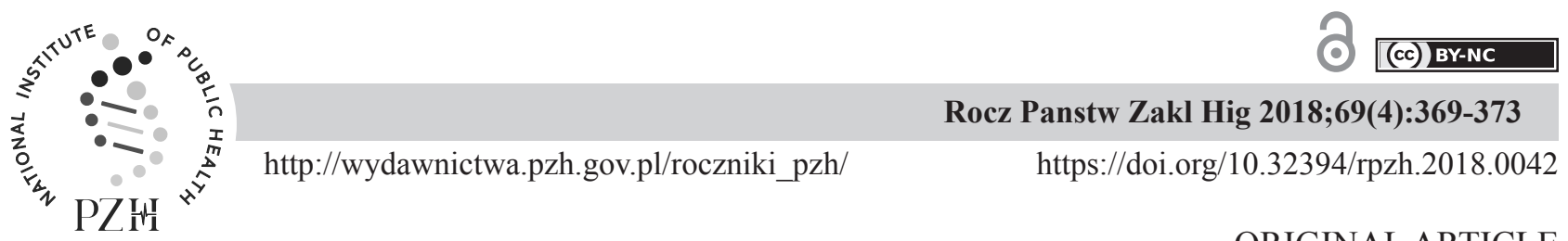

ORIGINAL ARTICLE

\title{
THE LEVEL OF PHYSICAL ACTIVITY IN ELDERLY PERSONS WITH OVERWEIGHT AND OBESITY
}

\author{
Izabela Zbrońska', Ewa Mędrela-Kuder² \\ ${ }^{1}$ Rehabilitation and Orthopedic Centre of Cracow, Poland \\ ${ }^{2}$ University of Physical Education, Faculty of Movement Rehabilitation, Department of Health Promotion, \\ Cracow, Poland
}

\begin{abstract}
Background. An important factor in maintaining elderly people in good health is an appropriate level of physical activity. The research into physical activity level of the elderly is quite crucial as the low level of such activity may lead to disability and that, in turn, generates the need of additional care which constitutes a serious social problem. As the existing data seem to lack a lot, new research would enrich our knowledge in new conclusions.

Objective. The aim of the study is to analyze and estimate the physical activity of the elderly persons with overweight or obesity elderly.

Material and methods. The research group consisted of 360 overweight and obese elderly people. The criteria of inclusion into a research group were living in family homes, overweight $\left(\mathrm{BMI}=25.0-29.9 \mathrm{~kg} / \mathrm{m}^{2}\right)$ or obesity $\left(\mathrm{BMI} \geq 30 \mathrm{~kg} / \mathrm{m}^{2}\right), \mathrm{no}$ contraindications to physical activity, age between 60 and 74 and written consent for the participation of the experiment. The control group consisted of 360 people without overweight and obesity. The inclusion criteria included age 60-74 $\mathrm{BMI}<25.0 \mathrm{~kg} / \mathrm{m}^{2}$ and living at family home. The data was gathered with the use of the International Physical Activity Questionnaire (IPAQ).

Results. The average age in the test group was $67,03 \pm 4,264$ and in control group $66,59 \pm 4,050$. The research has shown that the level of physical activity of overweight and obese senior citizens was lower than in people with correct body mass. Frequency of high intensity of physical activity undertaken by seniors in the test group was 0.7 day per week and lasted 16.1 minutes a day ( in the control group 2.5 days per day and 32.8 minutes per day, respectively). The IPAQ examination has shown that $95.8 \%$ of the test group participants had insufficient level of professional activity, $99.7 \%$ in transport-related physical activity, $86.1 \%$ in household chores and $99.4 \%$ in free time physical activity.

Conclusions. The level of physical activity of the elderly in the test group was very low, much lower than in people of the same age but with correct body mass. The lowest level of physical activity was noted in transport-related physical activity and leisure time physical activity.
\end{abstract}

Key words: physical activity, overweight, obesity, seniors, International Physical Activity Questionnaire, IPAQ

\section{STRESZCZENIE}

Wprowadzenie. Ważnym elementem w utrzymaniu osób starszych w dobrym zdrowiu jest odpowiedni poziom aktywności ruchowej. Badania aktywności ruchowej seniorów są bardzo istotne, bowiem niski jej poziom może prowadzić do niepełnosprawności seniorów, co generuje wiele potrzeb opiekuńczych, stanowiących znaczny problem społeczny. Literatura przedmiotu wykazuje poważną lukę w tym zakresie, a prowadzone badania pozwoliły na wzbogacenie jej o nowe wnioski. Cel badań. Celem badań była analiza i ocena aktywności ruchowej osób starszych z nadwagą i otyłością.

Materiał i metody. Grupa badana liczyła 360 osób starszych z nadwagą i otyłością. Kryterium włączenia do badań było zamieszkiwanie w domach rodzinnych, nadwaga $\left(B M I=25,0-29,9 \mathrm{~kg} / \mathrm{m}^{2}\right)$ lub otyłość $\left(\mathrm{BMI} \geq 30 \mathrm{~kg} / \mathrm{m}^{2}\right)$, brak przeciwwskazań do aktywności ruchowej, wiek pomiędzy 60 a 74 lata i uzyskanie pisemnej zgody pacjenta na udział w badaniu. Grupa kontrolna osób starszych bez nadwagi i otyłości liczyła 360 osób. Kryterium włączenia do badań był wiek 60-74 lata, $\mathrm{BMI}<25,0 \mathrm{~kg} / \mathrm{m}^{2}$, zamieszkiwanie w domu rodzinnym. Materiał badawczy zgromadzono wykorzystując Międzynarodowy Kwestionariusz Aktywności Fizycznej (IPAQ).

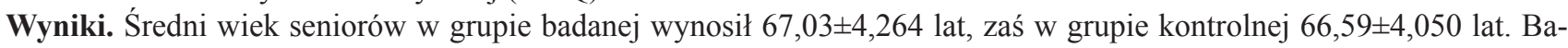
dania wykazały, że poziom aktywności ruchowej seniorów z nadwagą i otyłością był niższy niż osób z prawidłową masą ciała. Aktywność o wysokiej intensywności seniorzy z grupy badanej podejmowali średnio 0,7 dnia w tygodniu i trwała

Corresponding author: Ewa Mędrela-Kuder, Akademia Wychowania Fizycznego im. Bronisława Czecha w Krakowie, Wydział Rehabilitacji Ruchowej, Zakład Promocji Zdrowia, Al. Jana Pawła II 78, 31-571 Kraków, Polska, tel. +48 12 6831575, e-mail: ewa.medrela@awf.krakow.pl 
ona 16,1 minut dziennie (w grupie kontrolnej odpowiednio 2,5 dnia/tydzień i 32,8min/dzień). Niedostateczny poziom aktywności zawodowej w badaniu IPAQ stwierdzono u 95,8\% seniorów z nadwagą i otyłością, w zakresie przemieszczania się u 99,7\%, w zakresie prac domowych - u 86,1\%, a w czasie wolnym - u 99,4\%.

Wnioski. Poziom aktywności ruchowej seniorów w badanej grupie był bardzo niski, niższy niż osób w tym samym wieku z prawidłową masą ciała. Najniższy poziom aktywności stwierdzono w zakresie przemieszczania się i aktywności w czasie wolnym.

Słowa kluczowe: aktywność ruchowa, otytość, nadwaga, seniorzy, IPAQ

\section{INTRODUCTION}

Nowadays life expectancy has increased rapidly alongside with the lower birth rate which leads to the aging of the society. Median age in Poland in 1990 was 32.3 , in $2000-35.4$, in $2010-37.8$, in $2014-39.5$ and the estimated value in 2035 is 48 years of age [2]. As a result it leads to the growth in importance of physical activity in rehabilitation and condition improvement of the elderly. In many cases the recovery time after injuries of seniors and even their self-sufficiency depends heavily on life style and physical activity patterns.

Physical activity of the elderly shows close connection with their general physical and mental functioning and has a strong impact on life quality. Centre for Diseases Control and Prevention [10] and American College of Sports Medicine [8] recommend undertaking light or moderate physical activity in free time, not longer than 30 min per day and performed at least 5 times a week. There is no data concerning the activity of old, obese people in Poland regardless the fact that data $[5,7]$ suggests growing BMI index in people over 60 . The research carried out by Krzepota et al. [4] among students of The University of the Third Age the majority of women (60.4\%) and men (71.5\%) showed BMI over $25 \mathrm{~kg} / \mathrm{m}^{2}$.

The aim of the study was to analyse and estimate physical activity of overweight and obese elderly. An attempt was undertaken to determine a total daily activity and activity in four fields: professional, transport-related physical activity, household chores and free time physical activity.

\section{MATERIAL AND METHODS}

The data was collected in Małopolska (Lesser Poland) region among 720 people who participated in rehabilitation program in Rehabilitation Ward of Rehabilitation and Orthopedic Centre. The average age of all participants was $66.81 \pm 4.161$. The test group counted 360 overweight and obese people aged 60-74 (average age 67.03 \pm 4.264 ). The criteria of inclusion into a research group were living in family homes, overweight $\left(\mathrm{BMI}=25.0-29.9 \mathrm{~kg} / \mathrm{m}^{2}\right)$ or obesity $\left(\mathrm{BMI} \geq 30 \mathrm{~kg} / \mathrm{m}^{2}\right)$, no contraindications to physical activity, age between 60 and 74 and written consent to be part of the experiment.
The control group consisted of 360 people of the same age (average age 66.59 \pm 4.050 ) without overweight and obesity. The inclusion criteria included age 60-74, not suffering from chronic or psychiatric nor cancer diseases, without contraindications to physical activity and living at family home.

The research was carried out from May 2015 to March 2017 after acquiring the consent from the manager of Cracow Rehabilitation and Orthopedic Centre. The participants of the study gave their consent to be part of the experiment.

Standardized tool - the International Physical Activity Questionnaire (IPAQ) was used. The long version of IPAQ allows the estimation of total weekly energy expenditure (the sum of all the tested fields) and energy expenditure of professional life, transportrelated physical activity, household activities and free time physical activity. The results of physical activity were given in MET-min/week units [9]. Body indicators were obtained with the use of BIA TANITA BC-420MA. Statistical data analysis was performed with the use of IBM SPSS Statistics (ver. 21). P-value $p<0,05$ indicates the occurrence of statistically important differences or correlation.

\section{RESULTS}

The average body mass in the test group was $89.38 \pm 12.48 \mathrm{~kg}$ and was higher in women $(90.19 \pm 12.58$ $\mathrm{kg})$ than in men $(87.59 \pm 29.33 \mathrm{~kg})$. The average body mass in control group was $62.95 \pm 9.57 \mathrm{~kg}$ and was lower in men as well. BMI for men and women in both groups was similar. The average BMI in the test group was and $29.44 \pm 2.66 \mathrm{~kg} / \mathrm{m}^{2}$ and in the control group $21.31 \pm 1.77 \mathrm{~kg} / \mathrm{m}^{2}$.

The level of physical activity was established with the use of IPAQ questionnaire. MET-min/week values for physical activity, which were analyzed in four domains: professional, transport-related physical activity, household chores and free time physical activity, differed significantly in both groups $(\mathrm{p}<0.001)$. Test group participants were much more active in every tested field. Overweight and obese patients, despite being of the same age as those in the test group, rarely were professionally active, were less mobile and their physical activity as for household chores or free time activities was lower. It is reflected by statistically important 
differences between both groups $(\mathrm{p}<0.001)$ regarding the total amount of physical activity. The average MET value for the test group was $801.57 \pm 334.65$ whereas for the control group $1253.34 \pm 437.04$ (Table 1).

According to the IPAQ physical activity was divided into three levels [9]:

(1) Vigorous-intensity activity (three or more days per week of intense physical activity at min. 1500 MET or seven days any kind of combined physical activity (vigorous and moderate activities, walking) which together exceed 3000 MET,

(2) Moderate-intensity (three or more days per week of intense physical activity not shorter than $20 \mathrm{~min}$ per day or five or more days of moderate-intensity activity or walking not shorter than 30 minutes per day or five and more days of any combined physical activity (intense and moderate, walking) exceeding the total of $600 \mathrm{MET}$ ),

(3) Walking - low level of physical activity for patients showing no physical activity at all or not meeting the conditions for either moderate-intensity or high intensity physical activity.

Patients from the control group more frequently declared undertaking vigorous-intensity activity and differences observed between both groups were statistically important $(\mathrm{p}<0.001)$. Vigorous-intensity activity was undertaken by the participants of the test group average $0.7 \pm 1$ days per week which lasted
$16.1 \pm 44.17$ minutes per day. The same level of activity was declared by the participants of the control group $2.5 \pm 1.93$ days per week and it lasted $32.8 \pm 49.31$ minutes. Moderate-intensity physical activity was also much more frequently undertaken by senior citizens with correct body mass $(1.9 \pm 24.5$ days per week in the test group and 3.6 \pm 2.31 in control group). However, that kind of physical activity lasted longer in the test group (32.5 \pm 42.64 minutes per day) than in control group (24.8 844.89 minutes per day). Walking was more frequently reported by the members of the control group. Individuals from this group walked continuously not shorter than 10 minutes average $6.2 \pm 1.9$ times per week whereas those from the test group $4.9 \pm 2.43$ times per week. The average period of walking in overweight or obese patients was $61.70 \pm 48.83$ minutes per day and in case of the elderly with correct body mass $99.77 \pm 51.98$ minutes per day (Table 1 ).

The great majority of the tested patients did not undertake sufficient volume of physical activity (over $600 \mathrm{MET}-\mathrm{min} / \mathrm{week}$ ) in any of the domains. The control group individuals more often declared sufficient physical activity level in every domain. The differences between groups were significantly statistically important $(\mathrm{p} \leq 0.001)$ and statistically important $(p<0.05$ in the domain of work-related physical activity and household chores) (Table 2).

Table 1. Level of physical activity

\begin{tabular}{|l|c|c|c|c|c|c|c|c|}
\hline \multirow{2}{*}{ Level of Activity } & \multicolumn{2}{|c|}{ Seniors (general) } & \multicolumn{2}{c|}{ Women } & \multicolumn{3}{c|}{ Men } & \multicolumn{2}{c|}{ t-Student's test } \\
\cline { 2 - 9 } & & SD & & SD & & SD & t & $\mathrm{p}$ \\
\hline Professional job & 116.6 & 189.01 & 90.0 & 141.30 & 176.0 & 257.43 & -4.072 & 0.000 \\
\hline Mobility & 176.0 & 122.81 & 181.5 & 123.49 & 164.0 & 120.96 & 1.254 & 0.211 \\
\hline Housework & 342.3 & 190.17 & 337.5 & 187.52 & 352.9 & 196.36 & -0.707 & 0.480 \\
\hline Activity in free time & 167.0 & 144.78 & 170.3 & 147.78 & 159.6 & 138.31 & 0.646 & 0.519 \\
\hline Overall activity & 801.6 & 334.65 & 779.3 & 315.62 & 850.9 & 370.12 & -1.886 & 0.060 \\
\hline
\end{tabular}

Table 2. Average frequency of taking a physical effort and time of its duration

\begin{tabular}{|l|c|c|c|c|}
\hline \multirow{2}{*}{ Level of physical activity } & \multicolumn{2}{|c|}{ Average frequency (number, days, week) } & \multicolumn{2}{|c|}{ Duration (min/day) } \\
\cline { 2 - 5 } & & SD & \multicolumn{2}{c|}{ SD } \\
\hline Very intensive & 0.7 & 1.56 & 32.5 & 44.17 \\
\hline Average intensiv & 1.9 & 2.45 & 61.7 & 42.62 \\
\hline Walking & 4.9 & 2.43 & 49.83 \\
\hline
\end{tabular}

\section{DISCUSSION}

The matter of importance in measuring the volume of physical activity with the use of IPAQ questionnaire is the objectivity of the estimation and an opportunity to compare data from different regions and countries. That fact was the prevailing factor in choosing this method in our research. The obtained data has shown that the volume of physical activity in the overweight and obese elderly is very low, significantly lower than in the case of seniors with normal body weight. In the test group 360 patients sacrificed average 16.1 minutes daily to perform vigorous-intensity body activity, 32.5 minutes daily for moderate-intensity body activity and 61.7 minutes per day to walk (low intensity physical activity). The control group has shown 32.8, 24.8 and $99.7 \mathrm{~min} /$ day respectively. Due to the fact that there are no data which provide analysis of the level of activity of the overweight and obese elderly, it is only possible to compare our results with data showing physical activity volume in the elderly without BMI. 
The data provided by Biernat and Tomaszewski [1] shows that the level of physical activity measured with IPAQ in the elderly living in Warsaw is equally low. High-intensity physical activity was established at 23.93 $\mathrm{min} /$ day, moderate-intensity physical activity at 38.27 $\mathrm{min} /$ day and low-intensity physical activity (walking) at $41.27 \mathrm{~min} /$ day. Krzepota et al. [4] testing students of the University of the Third Age in Wałcz of the average age of 60.9 received similar results to ours. In the tested group in Wałcz the percentage of overweight and obese individuals was quite high ( $60.4 \%$ women, $71.5 \%$ men). The authors noticed that the intense physical activity was undertaken average 0.8 times a week (in our group of overweight and obese individuals 0.7 times a week) and it lasted 17.1 minutes per day (in our group 16.1 minutes per day). Moderate-intensity physical activity seniors estimated at average 1.9 times a week (in our group the same value 1.9 times a week) and it lasted $31.5 \mathrm{~min} /$ day (in our group $32.5 \mathrm{~min} /$ day). In the data by Dziedzic et al. the respondents suffered from ischaemic heart disease and declared undertaking physical activity more frequently than respondents in our study. There $31 \%$ of tested individuals claimed 30 minutes daily activity three times per week.

It should be underlined here that the problem of low physical activity level is not onle the problem of Polish senior citizens. Ogonowska-Stodownik [6] carried ot research in Norway among women aged
73.2. The author showed that the physical activity level of those women was higher than the one of women in our research. The IPAQ questionnaire showed that the vigorous-intensity activity was undertaken by Norwegian women about 32.7 minutes per day, moderate-intensity physical activity 23.6 minutes per day and walking - low level of physical activity - was taking 99.8 minutes per day.

In our research we have shown statistically important differences in the volume of physical activity of senior citizens depending on BMI. We observed statistically significant $(p<0.001)$ differences between the group of overweight and obese patients and the group with normal body weight in every analyzed domains of physical activity. Overweight and obese individuals in comparison to the control group were characterized by lower energy expenditure measured in MET in work-related physical activity, transportrelated physical activity, household chores and leisure time physical activity. The total volume of physical activity in overweight and obese individuals measured 1253.34 MET. Overweight and obesity may come as a consequence of lack of physical activity in case of old age individuals. However, Krzeptowska et al. [4] noticed quite a reversed tendency, namely, obesity was followed by lower percentage of individuals undertaking vigorous or moderate physical activity for the benefit of low intensity physical activity.

Table 3. Percentage of seniors with adequate level of physical activity

\begin{tabular}{|l|c|c|c|c|c|c|c|c|}
\hline \multirow{2}{*}{ Level of physical activity } & \multicolumn{2}{|c|}{$\begin{array}{c}\text { Professional } \\
\text { activity }\end{array}$} & \multicolumn{2}{|c|}{$\begin{array}{c}\text { Mobile } \\
\text { activity }\end{array}$} & \multicolumn{2}{|c|}{$\begin{array}{c}\text { Activity related } \\
\text { to housework }\end{array}$} & \multicolumn{2}{c|}{$\begin{array}{c}\text { Activity in free } \\
\text { time }\end{array}$} \\
\cline { 2 - 10 } & $\mathrm{n}$ & $\%$ & $\mathrm{n}$ & $\%$ & $\mathrm{n}$ & $\%$ & $\mathrm{t}$ & $\mathrm{p}$ \\
\hline Insufficent $(<600 \mathrm{MET} \times \mathrm{min} /$ week) & 345 & 95.8 & 359 & 99.7 & 332 & 92.2 & 358 & 99.4 \\
\hline Sufficient $(600-1500 \mathrm{MET} \times \mathrm{min} /$ week) & 14 & 3.9 & 1 & 0.3 & 25 & 6.9 & 2 & 0.6 \\
\hline High $(>1500 \mathrm{MET} \times \mathrm{min} /$ week) & 1 & 0.3 & 0 & 0.0 & 3 & 0.8 & 0 & 0.0 \\
\hline
\end{tabular}

Table 4. Level of physical activity in MET units and obesity or overweight

\begin{tabular}{|c|c|c|c|c|c|c|}
\hline \multirow{2}{*}{ Level of activity(MET) } & \multicolumn{2}{|c|}{ Overweight people } & \multicolumn{2}{|c|}{ Obese people } & \multicolumn{2}{|c|}{ Test t-Student's } \\
\hline & & SD & & SD & $\mathrm{t}$ & $\mathrm{p}$ \\
\hline Professional job & 118.69 & 196.853 & 114.18 & 179.907 & 0.225 & 0.822 \\
\hline Mobility & 168.53 & 120.525 & 184.80 & 125.224 & -1.254 & 0.211 \\
\hline Housework & 325.61 & 189.162 & 361.78 & 190.066 & -1.804 & 0.072 \\
\hline Freetime activity & 193.82 & 165.581 & 143.98 & 120.017 & -3.300 & 0.001 \\
\hline Overall activity & 853.89 & 327.618 & 756.81 & 334.946 & -2.769 & 0.006 \\
\hline
\end{tabular}

\section{CONCLUSIONS}

1. In the tested group of the overweight or obese elderly physical activity level was very low, much lower than in control group of individuals at the same age but normal body weight.

2. The lowest level of physical activity of the overweight or obese elderly was detected in the domain of transport-related physical activity and leisure time physical activity. The sufficient level of transport-related physical activity was performed by $0.3 \%$ individuals from the test group and free time physical activity by $0.6 \%$.

\section{Conflict of interest}

The authors declare no conflict of interest. 


\section{REFERENCES}

1. Biernat E., Tomaszewski P.: Socio-demographic and leisure activity determinants of physical activity of working Warsaw residents aged 60 to 69 years. J Hum Kinet 2011;3:173-181.

2. Ćwirlej-Sozańska A.: Aktywność fizyczna a stan zdrowia osób starszych. Przegl Med Uniw Rzesz Nar Inst Leków 2014;2:173-181.

3. Dziedzic B., Sienkiewicz Z., Imiela J.: Analiza wybranych zachowań zdrowotnych osób po 65 roku życia ze stwierdzoną chorobą niedokrwienna serca. Gerontol Pol 2015;3:89-100.

4. Krzepota J, Biernat E, Florkiewicz B.: Poziom aktywności fizycznej słuchaczy Uniwersytetu Trzeciego Wieku o zróżnicowanym indeksie masy ciała. MONZ 2013;19(2):200-205.

5. Myck M., Czapiński J., Dorabialski W., GiliSJanuszewska A., Kalbarczyk M., Kula G., Nicińska A., Topór-Mądry R., Wiśniewski M.: Zdrowie, praca i styl życia populacji $50+\mathrm{w}$ Polsce na tle innych krajów Europy. Warszawa, CenEA, 2009.

6. Ogonowska-Słodownik A.: Porównanie wyników kwestionariusza IPAQ, skali Borga oraz aktywności fizycznej norweskich osób starszych. Hyg Publ Health 2013;48(1):515-519
7. Pańczyk W: Aktywność fizyczna mieszkańców południowo-wschodnich regionów Polski u progu XXI wieku. W: Nowocień J., Chetmecki J. red. Społecznoedukacyjne oblicza współczesnego sportu i olimpizmu: aktywność fizyczna dzieci, młodzieży i dorosłych na przełomie XX i XXI wieku. Warszawa, AWF, 2010.

8. Pate R.R., Pratt M., Blair S.N., Haskell W.L., Macera C.A., Bouchard C., Buchner D., Ettinger W., Heath G.W., King A.C., Kriska A., Leon A.S., Marcus B.H., Morris J., Paffenbarger R.S., Patrick K., Pollock M.L., Rippe J.M., Sallis J., Wilmore J.H.: Physical activity and public health. A recommendation from the Centers for Disease Control and Prevention and the American College of Sports Medicine. JAMA 1995;273(5),: 402407.

9. Rosenberg D.E., Bull F.C., Marshall A.L., Sallis J.F., Bauman A.E.:Assessment of sedentary behavior with the International Physical Activity Questionnaire. J Phys Activ Health 2008;5(1):S0-S44.

10. US Department of Health and Human Services. 2008 Physical Activity Guidelines for Americans. Washington, The Secretary of Health and Human Services, 2009.

Received: 21.10 .2017

Accepted: 24.08 .2018

This article is available in Open Access model and licensed under a Creative Commons Attribution-Non Commercial 3.0.Poland License (CC-BY-NC) available at: http://creativecommons.org/licenses/by-nc/3.0/pl/deed.en 